\title{
THE MEDIATING ROLE OF GREEN ORGANIZATIONAL CULTURE BETWEEN SUSTAINABILITY AND GREEN INNOVATION: A RESEARCH IN TURKISH COMPANIES ${ }^{1}$
}

\author{
Mübeyyen TEPE KÜÇÜKOĞLU² \\ R. İbrahim PINAR ${ }^{3}$
}

\author{
Received Date (Başvuru Tarihi): 29/01/2018 \\ Accepted Date (Kabul Tarihi): 11/03/2018 \\ Published Date (Yayın Tarihi): 20/04/2018
}

\begin{abstract}
This study aims to examine Turkish companies from a sustainability and green innovation point of view. Through this purpose, this research's objective is to find out relationship between sustainability drivers and green innovation and also to search for green organizational culture's mediation effect in this relationship. Survey was carried in companies operating in Turkey which were listed among Istanbul Chamber of Industry (ICI) Top 500 companies for last 3 years successively and have ISO14001 Environmental Management Certificate. Acording to these criteria there are 224 companies in total and data gathered from 162 of them. Companies attended to this study are operating in different industries and most of them are in automotive, instruction, chemical and energy area. In order to test research hypotheses, correlation and regression analyses of quantitative methods were used.According to the survey results, it was manifested that factors directing companies to sustainability having a positive relationship with green organizational culture and green innovation. It is found that there is a partial mediation effect of green organizational culture between sustainability drivers and green innovation.
\end{abstract}

Keywords: Green Innovation, Green Organizational Culture, Sustainability, Sustainability Drivers

JEL Codes: M14, Q56

\section{SÜRDÜRÜLEBİLİRLIIK VE YEŞIL YENILİK İLISSKKISINDE YEŞIL ÖRGÜT KÜLTÜRÜNÜN ARACILIK ROLÜ: TÜRK İŞLETMELERİNDE BİR ARAŞTIRMA}

öz

Bu çalışma, sürdürülebilirlik ve yeşil yenilik bakış açıslyla Türk işletmelerini incelemeyi amaçlamaktadır. Bu amaç doğrultusunda, işletmeleri sürdürülebilirliğe iten faktörler ile yeşil yenilik arasındaki ilişki ve yeşil örgüt kültürünün bu ilişskideki aracllık rolü araştırlmaktadır. Araş̧trma modelini test etmek üzere Türkiye'de faaliyet gösteren, ISO500 listesine 3 yll üst üste girmeyi başarmış ve ISO 14001 Çevre Yönetim Sistemi Sertifikası'na sahip işletmelere uygulanan anket verileri kullanılmıştır. Bu kriterlere göre toplam 224 işletme bulunmakta ve söz konusu işletmelerin 162'sinden elde edilen anket verileri analiz edilmişstir. Araştırmada yer alan işletmeler farklı sektörlerde faaliyet göstermekte olup büyük bir kismı otomotiv, inşaat, kimya ve enerji sektörlerinde yer almaktadır. Araşttrma, hipotezlerinin test edilmesi için nicel analiz yöntemlerinden korelasyon ve regresyon analizleri uygulanmıştır. Araşstrma sonuçlarına göre, işletmeleri sürdürülebilirliğe iten faktörler ile yeşil örgüt kültürü ve

\footnotetext{
${ }^{1}$ Bu çalışma İstanbul Üniversitesi SBE’de yazılan “Sürdürülebilirlik ve Yeşil Yenilik Perspektifinde Türk İşletmelerinin İncelenmesi” adlı doktora tezinden üretilmiştir.

${ }^{2}$ Asst.Prof., Trakya University mtepekucukoglu@trakya.edu.tr http://orcid.org/0000-0002-3717-4165
}

${ }^{3}$ Prof., Istanbul Universtity, ipinar@istanbul.edu.tr 
yeşil yeniliğin ilişkili olduğu elde edilen bulgular arasındadır. Yeşil örgüt kültürünün işletmeleri sürdürülebilirliğe iten faktörler ile yeşil yenilik arasında kısmi aracılık etkisine sahip olduğu bulunmuştur.

Anahtar Kelimeler: Yeşil yenilik, Yeşil örgüt kültürü, Sürdürülebilirlik, Sürdürülebilirlik faktörleri

JEL Kodları: M14, Q56

\section{INTRODUCTION}

In today's world, when sustainability is referred to, the first definition that comes to mind relates to the continuity of resources for coming generations by using them consciously (WCED, 1987). Both in terms of its social aspect and the business perspective, sustainability is quite an important issue and has gained increasing attention on a daily basis. It is also a popular subject for conferences, meetings, congresses and campaigns in both scientific and nonscientific areas. Thanks to the attention being paid to sustainability, various solutions, proposals and ideas have been developed. From the business side, the results of business operations have an effect, not only on companies, but also on society; hence sustainability has become a matter that should be evaluated with a holistic approach.

It is obvious that companies have serious responsibilities regarding the environmental dimension of sustainability. This leads to crucial environmental effects as a result of their operational processes from beginning to end. It is possible to eliminate these effects through the use of certain preventive solutions. At this point, environmental-friendly technologies, especially activities that fall under the name of green innovation, are of great importance.

The concept of green innovation is not much different from the generally-known definition of innovation, but additionally includes the mission of decreasing the impact of environmental effects (Carrillo-Hermosilla et al., 2010). Companies implement green innovation applications in many areas in order to contribute to the environmental aspect of sustainability. These applications relate to product, process or organizational innovations (Cheng et al., 2014) including technological, organizational, social and institutional categories (Rennings, 2000).

There are many factors that trigger companies to engage in sustainability activities. In the literature, these factors are referred to as drivers or determinants of green innovation. These can be either company-specific internal or external factors (Law \& Gunasekaran, 2012). All of these factors have an important impact on the green innovational processes of companies. One of the research objectives of this study is to find out the extent of such an impact. Besides 
investigating relationships between the sustainability drivers as they relate to companies and green innovation, another research aspect of the study is to identify similar relationship between sustainability drivers and the green organizational culture. Here, the green organizational culture represents an organizational culture that encourages employees to engage in environmentally conscious behaviours and prepares a climate that allows the development of new ideas, behaviours or cooperation in such a way as to decrease the negative environmental effects of the company concerned (Chen, 2011). A green organizational culture enables an atmosphere to develop that encourages new ideas that lead to green innovations within the company. In this context, the effect of the environmental aspect of the existing organizational culture on green innovation performance is one of the research tasks of this study.

This research's objective is to find out relationship between sustainability drivers and green innovation and also to search for green organizational culture's mediation effect in this relationship. Although, in the literature, there are several studies about sustainability, organizational culture and innovation which also take into consideration environment factors, there is no research which investigates relationships among all these variables. For example, there are limited studies on environmental sustainability drivers in literature. Also, about green organizational culture we found quite a few researches. Green innovation is very fruitful subject, however relationship between green innovation and both sustainability drivers and green organizational culture is a new area. In this context, this study aims to fill this gap in the literature and to be one of the premised studies doing research into Turkish companies from a sustainability and green innovation point of view.

The paper is organized as follows. The next section presents review of literature and hypotheses development. Methodology section includes sample size and data collection, measurement, validity and reliability parts respectively.

In data analysis section, there are descriptive analysis that has demographic details of respondents and statistical values of research variables, correlation and regression analysis results. The paper ends with discussion and conclusions part.

\section{REVIEW OF LITERATURE AND HYPOTHESES DEVELOPMENT}

\subsection{Sustainability and Its Environmental Perspective}

Sustainability aims to ensure a trustworthy, healthy and high quality life for current and future generations of all the living creatures on the earth in an economic, social and 
environmental way (Gladwin et al., 1995). Sustainable development was firstly officially introduced in 1987 in the Brundtland Report as "...development that meets the needs of the present without compromising the ability of future generations to meet their own needs" (WCED, 1987). Prior to this official definition, a group of analysts published a report entitled "Limits to Growth" which introduced us to the sustainability concept in 1972. This report reviews interactions between economic systems and their subsystems and declared that if the global economy continues growing in the same way, limits will be exceeded by the 21 st Century and most probably population and economic systems will collapse if no fundamental changes are undertaken in political and behavioural terms (Turner, 2008).

Dangelico \& Pujari (2010) declare that challenges are becoming larger on a daily basis in terms of maintaining sustainability, and that companies should understand the importance of the integration of sustainability issues with their production processes. On the other hand, Labuschagne et al. (2005) comment on corporate sustainability that refers to protecting, maintaining and developing the human and natural resources which are necessary for the realization of facilities, and of business strategies to meet a company's and its stakeholders' requirements. It can be said that, sustainability has clearly become a way of doing business (Gobble, 2012).

From a business perspective, sustainability can be defined as a composite of social, environmental and economical practices within a company (Burke \& Gaughran, 2007) and a sustainable corporate financial performance is linked to social and environmental performance. This means that companies should evaluate their success in terms of sustainability, not only with financial results, but also in terms of environmental and social aspects (Tokgöz \& Önce, 2009).

Environmental sustainability aims to develop the welfare level of people by protecting raw material resources that are used to meet personal needs, and also by preventing various effects resulting from the creation of waste (Moldan et al., 2012). Cowan et al. (2010) analysed the sustainability reports of companies from different sectors, and stated that environmental sustainability programs can be split up into three main areas in the form of resource management, energy management and product sustainability. Henriques \& Sadorsky (1996) declare that policy makers, customers, shareholders, society and some other microenvironmental factors have a positive effect on companies in terms of persuading them to present an environmental plan. Company managers should strike a balance between corporate sustainability and a sustainable planet and society (Law \& Gunasekaran, 2012). 


\subsection{Green Innovation and Its Dimensions}

In the literature, there are several definitions of green innovation. Sometimes, ecoinnovation or environmental innovation is used with regard to the green innovation phrase. Generally, green innovation definitions emphasize decreasing negative impact or increasing positive effects on the environment through product, process or organizational innovations which serve environmental sustainability, and they have quite a close relationship with environmental management issues such as waste minimization and disposal, energy and material saving. There are some definitions from the literature:

"Environmental innovations can be defined as innovations which aim at reducing the negative environmental impacts caused by production methods (process innovations) and products (product innovations)" (Hemmelskamp, 1996)

"Environmental innovation consists of new or modified processes, techniques, systems and products to avoid or reduce environmental harms" (Kemp \& Arundel, 1998)

"Hardware or software innovation that is related to green products or processes, including the innovation in technologies that are involved in energy-saving, pollutionprevention, waste recycling, green product designs, or corporate environmental management" (Chen et al., 2006)

"Environmental innovations can be defined as innovations that consist of new or modified processes, practices, systems and products which benefit the environment and so contribute to environmental sustainability" (Oltra et al., 2009)

Green innovation is generally categorized as product, process or organizational based innovations (Cheng et al., 2014; Triguero et al., 2013). Ramus (2001) classifies green innovation types such as decreasing on the environmental impact of the company (reuse and recycling), solving an environmental problem for the company (hazardous substance use reduction) or developing a more eco-efficient product/service (fewer resources and/or energy intensive). On the other hand, some authors have classified green innovation in terms of the use of technologies such as clean technologies (clean products) or end-of-pipe applications (pollution control technologies, waste management, recycling, etc.) (Azzone, Bianchi, Mauri, \& Noci, 1997; Kemp \& Arundel, 1998). 


\subsection{The Relationship between Sustainability Drivers and Green Organizational Culture}

Environmental consciousness of companies is not spontaneous process. Hence, there are some accelerating factors which are called here as sustainability drivers. In literature, sustainability drivers separated into two groups as internal and external factors (Hart \& Milstein, 2003; Rodrigo, 2015) or in some researches into three groups adding management factor to these factors,. Company strategy and policies that supports sustainability and also top management's point of view take part in management factors. Internal factors include financial resources, knowledge and expertise, infrastructure, measuring system. Lastly, external factors are laws and regulations, social pressure, global market trend and competition (Law \& Gunasekaran, 2012). On the other hand, (Rodrigo, 2015) performed a study to answer the question 'What have been the drivers for corporate sustainability within the context of large corporations?' he conducted 13 semi-structured interviews with top-level corporate managers, complemented by three interviews with experts in the field. According to him main internal drivers are proactive leadership, business case, precautionary principle, company's culture and external drivers' reputation, customer demands and expectations, regulation and legislation. Each company's level of influence and reaction from either management, internal and external factors become different. This difference also reveals the level of adaptation of companies to sustainability.

Attention to the sustainability concept increases from both an academic and a social perspective. As a result of consuming resources rapidly and unconsciously, the value of unrenewable resources has increased. Conversely, companies have negative effects on the environment as a result of their activities. This situation highlights the environmental side of sustainability. Linnenluecke and Griffiths (2010) indicate that sustainability is understood and adopted by each company differently, depending on the prevailing type of organizational culture. From an environmental perspective, it is proposed that sustainability drivers enable an existing organizational culture to be more environmentally-oriented. Most of studies have not explicitly considered the links between sustainability drivers and green organizational culture. In this study, we therefore propose to contribute to the literature by exploring whether sustainability drivers affect green organizational culture.

Hypothesis 1: Sustainability drivers have a positive effect on green organizational culture 


\subsection{The Relationship between Green Organizational Culture and Green Innovation}

Some factors such as encouraging participation, increasing motivation, introducing rewards systems and incentives, better communication, the introduction of training activities will all be very important aspects for building a green culture within an organization (Fernandez et al., 2003; Govindarajulu \& Daily, 2004; Kane, 2011; Plank, 2011; Ramus, 2001; Zibarras \& Ballinger, 2010). Additionally, human resources departments play a crucial role when effectively bringing these issues to life (Julian \& Wells, 2011; Margaretha \& Saragih, 2013; Zibarras \& Ballinger, 2010).

According to Schein, organizational culture has three levels in the form of assumptions, values and artifacts from bottom to top respectively (Schein, 1990). These levels are also accepted as green organizational culture's levels (Crane, 1995). In the form of a simple definition, green organizational culture is the integration of environmental management with organizational culture (Margaretha \& Saragih, 2013). Green organizational culture defines a company's evaluation of the environment as a variable with values and norms (Azzone et al., 1997). Additionally, it is an interpretive and symbolic concept that guides all employees' behaviours and the company processes in terms of environmental management and protection (Chen, 2011). Green organizational culture-based companies recognize and analyse various issues, develop strategies, and solve their problems with the guidance of environmental values (Li et al., 2011). Hence, we proposed our second hypothesis:

Hypothesis 2: Green organizational culture has a positive effect on the green innovation performance of a company

\subsection{The Relationship between Sustainability Drivers and Green Innovation}

Beginning from the 1990s, some researchers have investigated the drivers of green innovations. Some of them have searched for the effect of environmental regulations; others have looked at supply- and demand-oriented factors. All these studies reveal heterogeneous discussions from both a methodological perspective and in terms of the results obtained (Belin et al., 2011). Doran \& Ryan (2016) indicates that the impact of supply- and demand-oriented and regulatory drivers vary across the different types of green innovation, it is consistently observed that existing regulation, customer expectations and voluntary agreements have a positive effect on the likelihood of firms' introducing green innovation. According to (Frondel et al., 2008) innovation behavior seems to be mainly correlated with the stringency of environmental policy. Specific policies and strategies include green company policies, 
environmental product policies and environmental strategic approaches (Dangelico, 2016). Technological trends or technological capabilities, market or customer demands, companyspecific factors such as strategies, are listed as the other main drivers (Cleff \& Rennings, 1999; Horbach, 2008; Rave et al., 2011; Rehfeld et al., 2007; Triebswetter \& Wackerbauer, 2008). Also clearly-defined sustainability goals trigger companies to innovate (Keskin et al., 2013). Therefore, sustainability has now been acknowledged as a key driver of innovation (Nidumolu et al., 2009). The following hypothesis therefore proposed:

Hypothesis 3: Sustainability drivers have a positive effect on the green innovation performance of company

\subsection{The Mediation Role of Green Organizational Culture between Sustainability Drivers and Green Innovation}

From the corporate point of view, it is not enough to just support pollution prevention through operations, minimizing resource allocation or selling greener products for being sustainable organizations or industries. They should think green and seek to be green (Harris \& Crane, 2002). Realization of sustainability on the part of companies depends on a cultural transformation including respect for the environment with an awareness of improved social responsibility (Crane, 1995). The ideological structure of organizational culture plays an important role in terms of ensuring successful cultural transformation. Therefore, organizational culture provides a climate to encourage sustainability outputs within an organization (Linnenluecke \& Griffiths, 2010). Culture management is necessary to encourage the implementation of green innovation (del Rosario et al., 2017). Hence, we propose our last hypothesis:

\section{Hypothesis 4: Green organizational culture has a mediation role between the sustainability drivers and green innovation}

In order to examine the above hypotheses, the proposed conceptual research model of this research is as shown in Figure 1. 


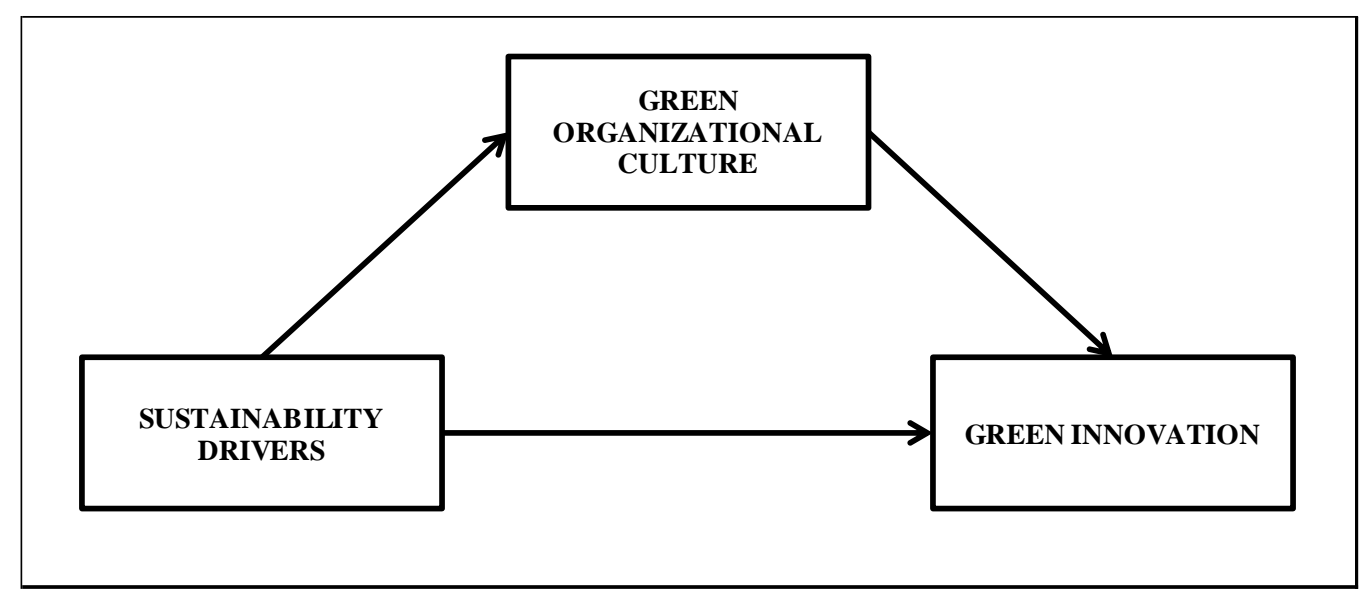

Figure 1: Research Modal

\section{RESEARCH METHODOLOGY}

\subsection{Sample Size and Data Collection}

In this research context, a survey study was conducted among the 500 biggest companies in Turkey according to the list published annually by the ICI based on sales revenue ("ISO," 2013). This list is referred to as ICI Top 500. The population of this study constituted the 500 biggest Turkish companies is determined according to certain criteria. One of these criteria is to have been in the list for 3 consecutive years between 2010 and 2012 in order to be seen as a stable company. Secondly, companies should be in possession of the ISO14001 Environmental Management System Certificate. After the first elimination, the websites of the remaining companies were searched to see if they possessed the ISO 14001 certificate. Based on the first and second criteria, a total of 224 companies were obtained which then represented the population of the study. The common characteristics of the companies that were included in the population of this study are summarized as below:

(1) Companies should have their operations in Turkey

(2) Companies should obtain their sales revenue from their production activities

(3) Companies should be on the ICI Top 500 list during years 2012, 2011 and 2010

(4) Companies should be in possession of the ISO 14001 Environmental Management System Certificate

Companies that have above characteristics were accepted as being suitable for the purpose of this study and for being applicable in terms of the research model. On-line survey forms were sent to all companies that represented the population. For the companies which 
provided no feedback or answered the survey, a reminder e-mail was sent and then they were called by telephone. Some of the companies would not answer the survey because of their company policy. The survey was therefore completed with the participation of 162 companies in total.

\subsection{Measurement}

The survey form has 4 sections. The first section contains the aim of the survey and some of the descriptive information requested, such as gender and the department of the respondents, company size and industry, ownership of any environmental award and duration of ISO14001 certification. Other sections include questions about each of the research variables in the form of sustainability drivers, green organizational culture and green innovation respectively. The sustainability drivers scale was developed by (Law \& Gunasekaran, 2012), the green organizational culture scale was adapted from the study of (Zibarras \& Ballinger, 2010), the green innovation scale was developed from (Chen et al., 2006) and (Chiou et al., 2011). All scales were translated from English to Turkish by the researchers of this study. The survey has 5-point Likert-type answer options from 1 (strongly disagree) to 5 (strongly agree).

\subsection{Validity and Reliability}

Validity and reliability analyses were performed for each scale. For construct validity, the Kaiser-Meyer-Olkin sample validity co-efficient was calculated and factor analysis was undertaken.

In this study, after the translation of each scale, we asked the opinions of academics and some other authorities from sustainability, environment and quality departments from a number of companies about the clarity of the items and the propriety of the words and sentences used as a means of determining content validity. According to the feedback received, some corrections were made. Then exploratory factor analysis was applied to determine the construct validity of each scale. For all scales, in terms of factor analysis, Principal Component Analysis and Varimax with the Kaiser Normalization Rotation Method were used.

Reliability analysis explains how accurately a measurement tool is in terms of measuring the research variable. The most commonly used reliability co-efficient is Cronbach's Alpha in reliability analysis. Suggested minimum $\alpha$ value is 0.70 (Uzgören, 2012).

For the sustainability drivers scale, all items were collected with regard to two factors. The first was referred to as internal drivers while the second one was referred to as external drivers. Drivers belonging to management within the Law \& Gunasekaran's study (2012) were 
identified as internal drivers here. According to the factor analysis results, total variance was found as being $61.718 \%$ and this variance was explained $40.181 \%$ in terms of the internal drivers and $21.537 \%$ in terms of the external drivers. Internal drivers were presented in the form of 7 items and external drivers in the form of 4 items. The scale had 11 items in total after factor analysis. These two factors had reliability values of 0.901 and 0.706 respectively. Scale reliability was found to be 0.854 .

The second variable considered in this study, the green organizational culture scale, also had two factors in the form of green behaviour development and green behaviour evaluation. Total variance was found to be $65.826 \%$, the green behaviour development factor explained $42.480 \%$ of the total variance and the green behaviour evaluation factor explained $23.345 \%$ of total variance according to the factor analysis results. Following reliability analysis, the Cronbach's Alpha value for this scale was 0.942. Green behaviour development had 13 items and the Cronbach's Alpha value was 0.952. Green behaviour evaluation had 4 items, and the Cronbach's Alpha value was found to be 0.837 .

Regarding the last variable's factor analysis result, the scale had two factors in the form of green products and process innovation. The green innovation scales' total variance was $61.995 \%$. Green product innovation, having 4 items, explained $31.425 \%$ of the total variance and had a 0.861 Cronbach's Alpha value. Green process innovation explained $30.570 \%$ of total variance and, in terms of reliability analysis, the Cronbach's Alpha value was found to be 0.777 which is acceptable. It had 5 items.

\section{DATA ANALYSIS}

\subsection{Descriptive Analysis}

First of all, frequency distribution was calculated for the respondents' departments and gender, company size, industry, environment award ownership and ISO14001 certificate duration. In addition, mean and standard deviation values were found. Secondly, in order to test hypotheses, correlation and regression analyses were performed. All analyses were performed using the SPSS 20.0 program.

Details of the demographic statistics of the respondents and also some characteristics of the companies involved are shown in Table 1. Demographic information relating to the respondents indicates that most of them were male (122 of 164 respondents with $75 \%$ ) and employed mostly in sustainability and environment (41 respondents), R\&D ( 39 respondents) or quality-related departments (32 respondents). Most of the companies were large ( 102 of 162 
companies) or very large (45 of 162 companies) with $91 \%$, they had their facilities mostly in the automotive (46 of 162) with $28 \%$, construction (27 of 162) with 17\%, chemical ( 22 of 162) with $14 \%$ or energy industries (16 of 162) with $10 \%$. Additionally, $72 \%$ of the companies had been in possession of the ISO14001 environmental management system certificate for more than 5 years, and $56 \%$ of these companies had an environmental award. All details are given in Table 1.

Table 1: Demographic Details of Respondents

\begin{tabular}{|c|c|c|c|c|c|}
\hline & $\mathbf{N}$ & $\%$ & & $\mathbf{N}$ & $\%$ \\
\hline Company size & & & Industry & & \\
\hline Large (251-2000) & 102 & 63 & Automotive & 46 & 28 \\
\hline Very large $(>2000)$ & 45 & 28 & Construction & 27 & 17 \\
\hline Medium (51-200) & 13 & 8 & Chemical & 22 & 14 \\
\hline Small (1-50) & 2 & 1 & Energy & 16 & 10 \\
\hline Departments & & & Food & 13 & 8 \\
\hline Sust., environment \& work safety & 41 & 25 & Other/Defense,Iron\&steel, etc. & 13 & 8 \\
\hline R\&D and P\&D (production and dev.) & 39 & 24 & Textile & 11 & 7 \\
\hline Quality & 32 & 20 & White goods & 8 & 5 \\
\hline Production & 20 & 12 & Packaging & 6 & 4 \\
\hline Other & 17 & 11 & Environmental reward ownership & & \\
\hline Top management & 13 & 8 & Yes & 90 & 56 \\
\hline ISO 14001 certificate duration & & & No & 55 & 34 \\
\hline$>10$ years & 74 & 46 & Don't know & 17 & 10 \\
\hline $5-9$ years & 43 & 26 & Gender & & \\
\hline $0-4$ years & 26 & 16 & $\mathrm{~F}$ & 40 & 25 \\
\hline No answer & 19 & 12 & M & 122 & 75 \\
\hline
\end{tabular}

With data obtained from the survey results, the statistical values of each variable were calculated in the form of maximum, minimum, average value and standard deviation. With an average value close to 4.00 for all variables - sustainability drivers, green organizational culture and green innovation, - the general status of the companies is at a good level. That means; for companies in this research, sustainability drivers are effective, green organizational culture is common within the company and green innovation is adopted and used. Statistical values of each variable are shown in Table 2.

Table 2: Statistical Values of Research Variables

\begin{tabular}{|l|c|c|c|c|}
\hline & Minimum & Maximum & Average & Standard deviation \\
\hline Sustainability drivers & 2,46 & 5,00 & 3,94 & 0,55 \\
\hline Green organizational culture & 1,47 & 4,95 & 3,94 & 0,60 \\
\hline Green innovation & 2,54 & 5,00 & 3,98 & 0,58 \\
\hline
\end{tabular}




\subsection{Correlation Coefficients}

In order to define relationships between research variables, Pearson Correlation Analysis was applied. Table 3 shows the correlation analysis results.

Table 3: The Correlation Coefficient Matrix

\begin{tabular}{|c|c|c|c|c|c|c|c|c|c|}
\hline Variables & 1 & 2 & 3 & 4 & 5 & 6 & 7 & 8 & 9 \\
\hline 1.Sustainability drivers & 1 & $.901 * *$ & $.678^{* *}$ & $.564 * *$ & $.573^{* *}$ & $.434 * *$ & $.491 * *$ & $.451 * *$ & $.419 * *$ \\
\hline 2.Internal factors & & 1 & $.293 * *$ & $.631 * *$ & $.653^{* *}$ & $.353 * *$ & $.512 * *$ & $.476^{* *}$ & $.432 * *$ \\
\hline 3.External factors & & & 1 & $.176^{*}$ & $.158^{*}$ & $.159^{*}$ & $.215^{* *}$ & $.189^{*}$ & $.191 *$ \\
\hline $\begin{array}{l}\text { 4.Green organizational } \\
\text { culture }\end{array}$ & & & & 1 & $.964 * *$ & $.739 * *$ & $.621 * *$ & $.449 * *$ & $.626 * *$ \\
\hline $\begin{array}{l}\text { 5.Green behavior } \\
\text { development }\end{array}$ & & & & & 1 & $.535^{* *}$ & $.622 * *$ & $.459^{* *}$ & $.620 * *$ \\
\hline 6.Green behavior evaluation & & & & & & 1 & $.400 * *$ & $.266^{* *}$ & $.422 * *$ \\
\hline 7.Green innovation & & & & & & & 1 & $.850 * *$ & $.907 * *$ \\
\hline 8.Green product innovation & & & & & & & & 1 & $.549 * *$ \\
\hline 9.Green process innovation & & & & & & & & & 1 \\
\hline
\end{tabular}

It is clear that sustainability drivers have a positive medium level correlation (or close to the medium level) with green organizational culture and green innovation variables. When we review internal factors and external factors in detail, we can see that especially external factors have a weak positive correlation with all variables. Secondly, there is also a medium level correlation between green organizational culture and green innovation. In summary, all variables and their sub-dimensions have positive relationships with each other in different degrees.

\subsection{Regression Analysis}

As a statistical tool, regression analysis indicates the causal effect of an independent variable on a dependent variable (Durmuş et al., 2013; Uzgören, 2012).

To test the first, second and third hypotheses, multiple regression analyses was applied. Table 4 shows regression analysis results. In multiple regression analysis, the stepwise method was used. In the first step, the internal factors sub-dimension was applied to the analysis and then, for the second step, the external factors were added. According to the results, in the first step, the effect of the internal factors on green organizational culture was significant $(\mathrm{p}<0.05)$. Internal factors explained $39.4 \%$ of the variance in terms of the green organizational culture. In the second step, when external factors were added to the analysis, the results became statistically insignificant for external factors $(p>0.05)$. Only the internal factors of the sustainability drivers variable was found to have an effect on green organizational culture. As 
the second sub-dimension was statistically insignificant according to the multiple regression analysis, hypothesis 1 was partially supported.

Multiple regression analysis indicated that the green behaviour development subdimension of green organizational culture explained $38.3 \%$ of the variance in green innovation performance $(\mathrm{p}<0.05)$. However, when the green behaviour evaluation sub-dimension was added to the analysis, the contribution of this sub-dimension to the model became statistically insignificant $(\mathrm{p}>0.05)$. Only the green behaviour development sub-dimension of green organizational culture had an effect on green innovation. As with hypothesis 1, hypothesis 2 was also partially accepted

In order to test the third hypothesis, we found that internal factors explained $25.8 \%$ of the green innovation performance. However, external factors had no statistically significant effect on green innovation performance ( $p>0.05)$. Hypothesis 3 was partially supported.

Table 4: Simple and Multiple Regression Analyses Results

\begin{tabular}{|c|c|c|c|c|c|c|c|}
\hline \multirow{2}{*}{$\begin{array}{l}\text { Dependent variable: } \\
\text { Green organizational culture }\end{array}$} & \multicolumn{2}{|c|}{ Model Summary } & \multicolumn{2}{|c|}{$\begin{array}{c}\text { ANOVA table } \\
\text { summary }\end{array}$} & \multicolumn{3}{|c|}{ Coefficient table summary } \\
\hline & $\mathbf{R}^{2}$ & Adjusted $\mathbf{R}^{2}$ & $\mathbf{F}$ & Sig. level & Std. Beta & $t$ value & \multirow[t]{2}{*}{ Sig. level } \\
\hline $\begin{array}{l}\text { 1. Step: } \\
\text { Independent variable: } \\
\text { Internal factors }\end{array}$ & .398 & .394 & 105.738 & .000 & .631 & 10.283 & \\
\hline $\begin{array}{l}\text { 2. Step: } \\
\text { Independent variables: } \\
\text { Internal factors } \\
\text { External factors } \\
\end{array}$ & .398 & .390 & 52.560 & .000 & $\begin{array}{r}.634 \\
-.010 \\
\end{array}$ & $\begin{array}{l}9.847 \\
-.160 \\
\end{array}$ & $\begin{array}{l}.000 \\
.873 \\
\end{array}$ \\
\hline Dependent variable: & \multicolumn{2}{|c|}{ Model Summary } & \multicolumn{2}{|c|}{$\begin{array}{c}\text { ANOVA table } \\
\text { summary }\end{array}$} & \multicolumn{3}{|c|}{ Coefficient table summary } \\
\hline Green innovation & $\mathbf{R}^{2}$ & Adjusted R ${ }^{2}$ & $\mathbf{F}$ & Sig. level & Std. Beta & $t$ value & Sig. level \\
\hline $\begin{array}{l}\text { 1. Step: } \\
\text { Independent variable: } \\
\text { Green behavior development }\end{array}$ & .387 & .383 & 100.982 & .000 & .622 & 10.049 & .000 \\
\hline $\begin{array}{l}\text { 2. Step: } \\
\text { Independent variables: } \\
\text { Green behavior development } \\
\text { Green behavior evaluation }\end{array}$ & .393 & .386 & 51.541 & .000 & $\begin{array}{l}.571 \\
.095\end{array}$ & $\begin{array}{l}7.819 \\
1.294\end{array}$ & $\begin{array}{l}.000 \\
.198\end{array}$ \\
\hline Dependent variable: & \multicolumn{2}{|c|}{ Model Summary } & \multicolumn{2}{|c|}{$\begin{array}{c}\text { ANOVA table } \\
\text { summary }\end{array}$} & \multicolumn{3}{|c|}{ Coefficient table summary } \\
\hline Green innovation & $\mathbf{R}^{2}$ & Adjusted $\mathbf{R}^{2}$ & F & Sig. level & Std. Beta & $t$ value & Sig. level \\
\hline $\begin{array}{l}\text { 1. Step: } \\
\text { Independent variable: } \\
\text { Internal factors }\end{array}$ & .263 & .258 & 56.980 & .000 & .512 & 7.548 & .000 \\
\hline $\begin{array}{l}\text { 2. Step: } \\
\text { Independent variables: } \\
\text { Internal factors } \\
\text { External factors } \\
\end{array}$ & .267 & .258 & 28.993 & .000 & $\begin{array}{l}.492 \\
.071 \\
\end{array}$ & $\begin{array}{l}6.922 \\
1.002\end{array}$ & $\begin{array}{l}.000 \\
.318\end{array}$ \\
\hline
\end{tabular}


According to regression analysis results external factors with regard to the subdimension of sustainability drivers and green behaviour evaluation with regard to the subdimension of green organizational culture are not included in further analyses because of statistically insignificant results in terms of the multiple regression analysis. Sustainability drivers variable is presented with only internal factors, and the green organizational culture variable is presented with green behaviour development sub-dimension for mediating effect analysis.

For the last hypothesis, we used (Baron \& Kenny, 1986)'s three step approach in order to find out if there is a mediation effect of the green organizational culture. According to (Baron \& Kenny, 1986), a variable's mediator role should be searched using the following steps:

(1) The independent variable should have an effect on the mediator variable

(2) The independent variable should have an effect on the dependent variable

(3) When the mediator variable is added to the regression analysis during the third step, if a relationship between independent and dependent variables becomes statistically insignificant, then a full mediation effect occurs; otherwise, if there is a decrease in the relationship between the independent and dependent variables, then a partial mediation effect occurs.

First of all, independent variable sustainability drivers and mediating variable green organizational culture were put into the regression analysis. The first step regression analysis indicated that sustainability drivers were significantly related to green organizational culture $(\beta=0.653 ; \mathrm{p}<0.05)$. Then the second step regression analysis was conducted between the sustainability drivers and the dependent variable green innovation performance. There was a positive and significant effect of sustainability drivers on green innovation performance $(\beta=0.512 ; p<0.05)$. After that, the mediating variable green organizational culture was added to the analysis, and there was a positive and significant effect of green organizational culture on green innovation performance $(\beta=0.520, \mathrm{p}<0.05)$. However, the $\beta$ coefficient of sustainability drivers decreased from 0.512 to $0.177(\mathrm{p}<0.05)$. With this result, it is obvious that there is a partial mediating effect of green organizational culture on the relationship between sustainability drivers and green innovation performance. Hypothesis 4 was supported with this result. Table 5 shows regression analysis result. 
Table 5: Regression Analysis Result of Mediating Effect

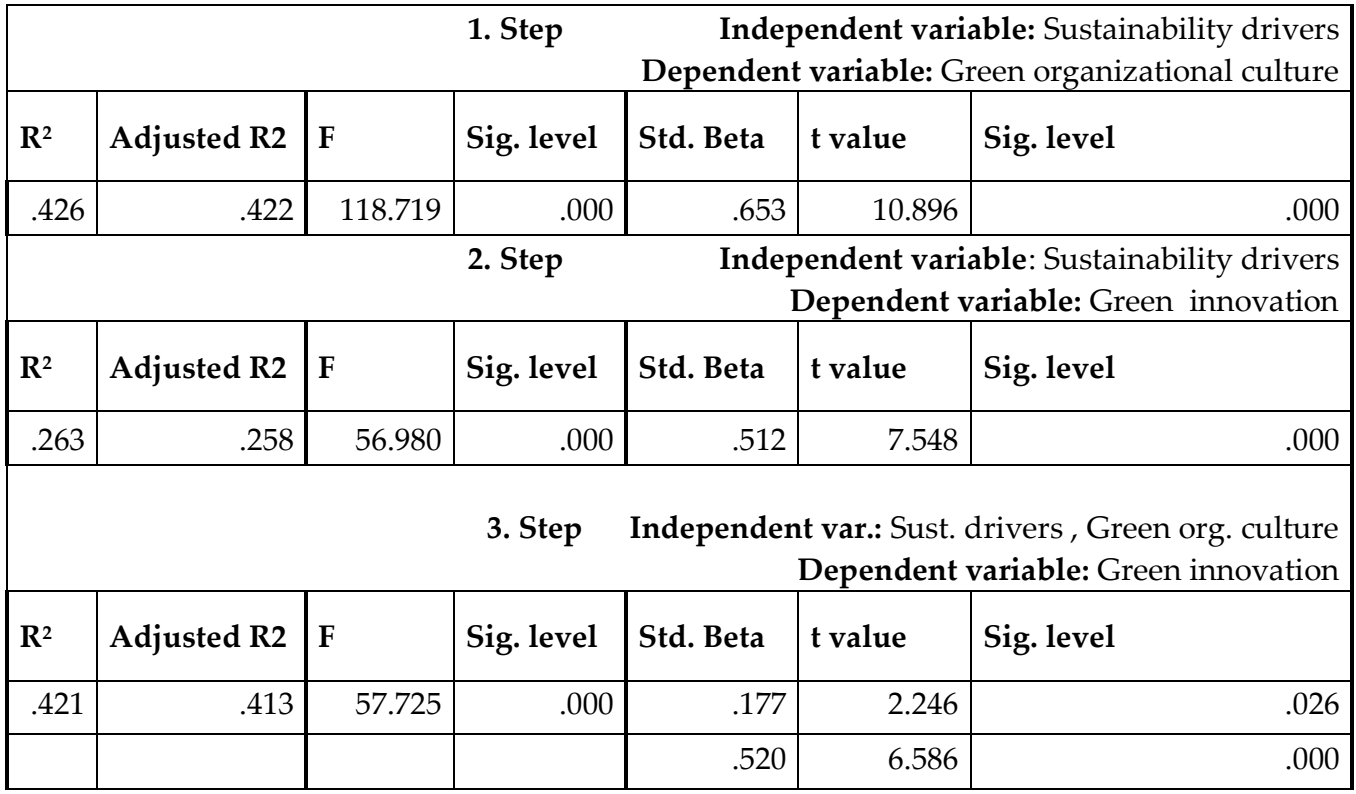

\section{DISCUSSION AND CONCLUSIONS}

Sustainability is defined in basic terms as today's resources' continuity for the coming generations. From a corporate perspective, one of the main goals of companies is to remain in existence in the future. Hence, their goal is in line with the sustainability philosophy. It is not possible to imagine a company that survives in a world while consuming resources unconsciously and harming its environment with its operations. From the environmental point of view associated with sustainability, there are some factors which trigger companies in directing some different processes on behalf of maintaining current methods and facilities. Law \& Gunasekaran (2012) identified key factors influencing the adoption of sustainability development strategies on the part of companies. These factors were entitled sustainability drivers and are classified as internal factors and external factors. This study investigating these factors from Turkish companies' perspective finds that internal factors are more effective than external factors in generating action on the part of companies.

Under the effect of sustainability drivers, while companies put operations into place in such a way as to minimize their negative effects on the environment, and also to use their production resources more productively, these companies shift to certain changes in their products and processes. One of these changes is associated with green innovation activities. On the other hand, organizational culture plays an important role when companies are realizing green innovation activities. If a company's organizational culture has a tendency to support 
green behaviours and this leads to an emphasis on the importance of developing new ideas, then it enables the company to increase total value and serves to achieve the company's targets.

This study aims to be original in terms of investigating interactions among sustainability drivers, green organizational culture and green innovation performance in Turkish companies and fill the gap in this area. The results of this study lead to some contributions to the management literature. First, the results show that sustainability drivers have a relationship with both green organizational culture and green innovation performance. From management point of view, companies need to take into account these three elements together. For example, sustainability drivers express factors that trigger companies for realizing some activities regarding environmental sustainability. Developing environmental sustainability inside the company is achieved through people, which means employers. When employers act to serve environmental sustainability then organizational culture will shape on this way. It means, environmental sustainability helps building green organizational culture. Moreover, if environmental sustainability develops within the company then innovation activities are also supported by this way. Innovation will have its own share from environmental perspective.

However, according to findings of this research; external factors have no effect on developing a green organizational culture and realizing both green product and process innovations. Hence, improvements in this area are the outcome of internal factors. The internal factors presented here are the personal interest of the top management, supporting policies, promoting business objectives, sufficient financial support, specific knowledge and expertise, well-developed infrastructure, and effective measuring systems to monitor performance. The external factors; law and regulations, market trend and social pressure have no significant effect on both green organizational culture and green innovation. Similarly, (Frondel et al., 2008) supports our findings with their research results. They reports that rather than external factors, such as regulatory pressure, exclusively facility-related internal factors, such as management employees and enhancement of corporate image, appear to be important for the decision in favor of EMS adoption. Apart from policy stringency and the influence of public authorities, these internal factors are also likely to be the driving force for a facility's abatement activities.

Evaluating this research in terms of its findings shows that some factors do not reflect the expected results. These results are difficult to explain. Taking into consideration certain dynamics in Turkey, it is possible to comment differently. There can be some reasons associated with finding the external factors' effect on green innovation to be statistically insignificant. Regarding environmental protection there are limited law and regulations which have limited 
restrictions and penalties for companies to act in sustainable and environmental-friendly manner. Environmental protection and sustainability is very important subject of Turkey's future agenda, so there are some ongoing arrangements and regulations for the next term. Also, companies feel very few pressures from customers and social communities regarding environmental issues. For example, customers sometimes pay attention to product price much more than other factors. Lack of enough non-profit organizations and societies that supports environmental facts in Turkey reveals external factors' ineffectiveness on this study.

Secondly, green organizational culture has an effect on green innovation activities. The green behaviour evaluation sub-dimension of green organizational culture has very low relationship with green innovation performance, and its effect on green innovation performance is found to be statistically insignificant. This result highlights lack of enough practices within companies to evaluate and support positive environmental behaviours such as reward systems. Otherwise, the green organizational culture without a green behaviour evaluation subdimension has a partial mediating effect on the relationship between sustainability drivers and green innovation performance. Accordingly, Turkish companies target green products and process innovations as motivated by internal factors. This situation is improved by an organizational culture which gives importance to the environment.

Today, companies increasingly pay attention to environmental activities and day-byday, more companies are known in terms of their green activities. It is obvious that, together with growing consciousness, companies' activities in terms of environmental protection and green innovation will increase in the coming years. Therefore, it is suggested that there is a need to repeat this research at a later date to observe improvements in this area.

This research was performed with companies which already had an ISO14001 certificate and had been on the ISO500 list for three years consecutively in 2010, 2011 and 2012. Renewing this research with a new company population taken from the next ISO500 list will also give feedback about the consistency of the results and allow us to observe any changes in the external factors' effect.

This study was performed among companies which operate in Turkey. Limitation of research population of this study with just one country inhibits generalization of research results. It is recommended that similar research be undertaken for other countries and for a comparison of the outcomes to allow for a generalization of the research findings. It can be beneficial to think this study within the European context of green innovation for further studies. 
Lastly, ISO certification for environment management in companies brings changes to organizational culture to be more than a compliance exercise. Hereby, a comparison between certified and not certified companies as taking into account whole population of ICI500 companies to control out certification as a default for green organizational culture and innovation. 


\section{REFERENCES}

Azzone, G., Bianchi, R., Mauri, R., \& Noci, G. (1997). Defining operating environmental strategies: programmes and plans within Italian industries. Environmental Management and Health, 8(1), 4-19. http://doi.org/10.1108/09566169710159159

Baron, R. M., \& Kenny, D. A. (1986). The Moderator-Mediator Variable Distinction in Social Psychological Research: Conceptual, Strategic, and Statistical Considerations. Journal of Personality and Social Psychology, 51(6), 1173-1182.

Belin, J., Horbach, J., \& Oltra, V. (2011). Determinants and specificities of eco-Innovations-an econometric analysis for the French and German industry based on the community innovation survey (No. 17). Retrieved

from 10.1080/13662716.2013.833375\%5Cnhttp://search.ebscohost.com/login.aspx?direct=true\&db=bth\&AN $=91674580 \&$ site $=$ ehost-live

Burke, S., \& Gaughran, W. F. (2007). Developing a framework for sustainability management in engineering SMEs. Robotics and Computer-Integrated Manufacturing, 23(6), 696-703. http://doi.org/10.1016/j.rcim.2007.02.001

Carrillo-Hermosilla, J., Del Río, P., \& Könnölä, T. (2010). Diversity of eco-innovations: Reflections from selected case studies. Journal of Cleaner Production, 18(10-11), 1073-1083. http://doi.org/10.1016/j.jclepro.2010.02.014

Chen, Y.-S. (2011). Green organizational identity: sources and consequence. Management Decision, 49(3), 384 404. http://doi.org/10.1108/00251741111120761

Chen, Y.-S., Lai, S.-B., \& Wen, C.-T. (2006). The Influence of Green Innovation Performance on Corporate Advantage in Taiwan. Journal of Business Ethics, 67(4), 331-339. http://doi.org/10.1007/s10551-0069025-5

Cheng, C. C. J., Yang, C. L., \& Sheu, C. (2014). The link between eco-innovation and business performance: a Taiwanese industry context. Journal of Cleaner Production, 64, 81-90. http://doi.org/10.1016/j.jclepro.2013.09.050

Chiou, T.-Y., Chan, H. K., Lettice, F., \& Chung, S. H. (2011). The influence of greening the suppliers and green innovation on environmental performance and competitive advantage in Taiwan. Transportation Research Part E: Logistics and Transportation Review, 47(6), 822-836. http://doi.org/10.1016/j.tre.2011.05.016

Cleff, T., \& Rennings, K. (1999). Determinants of environmental product and process innovation. European Environment, 9(5), 191-201. http://doi.org/10.1002/(SICI)1099-0976(199909/10)9:5<191::AIDEET201>3.0.CO;2-M

Cowan, D. M., Dopart, P., Ferracini, T., Sahmel, J., Merryman, K., Gaffney, S., \& Paustenbach, D. J. (2010). A cross-sectional analysis of reported corporate environmental sustainability practices. Regulatory Toxicology and Pharmacology, 58(3), 524-538. http://doi.org/10.1016/j.yrtph.2010.09.004

Crane, A. (1995). Rhetoric and Reality in the Greening of Organizational Culture. Greener Management International, (12), 50.

Dangelico, R. M. (2016). Green Product Innovation: Where we are and Where we are Going. Business Strategy and the Environment, 25(8), 560-576. http://doi.org/10.1002/bse.1886

Dangelico, R. M., \& Pujari, D. (2010). Mainstreaming green product innovation: why and how companies integrate environmental sustainability. Journal of Business Ethics, 95(3), 471-486. http://doi.org/10.1007/s10551010-0434-0

del Rosario, R.-S. M., Patricia S., S.-M., \& René, D.-P. (2017). Eco-innovation and organizational culture in the hotel industry. International Journal of Hospitality Management, 65, 71-80. http://doi.org/10.1016/J.IJHM.2017.06.001

Doran, J., \& Ryan, G. (2016). The Importance of the Diverse Drivers and Types of Environmental Innovation for Firm Performance. Business Strategy and the Environment, 25(2), 102-119. http://doi.org/10.1002/bse.1860

Durmuş, B., Yurtkoru, S. E., \& Çinko, M. (2013). Sosyal Bilimlerde SPSS'le Veri Analizi (5. Edition). İstanbul: Beta Yayınc1lık. 
Fernandez, E., Junquera, B., \& Ordiz, M. (2003). Organizational culture and human resources in the environmental issue: a review of the literature. International Journal of Human Resource Management, 14(4), 634-656. http://doi.org/10.1080/0958519032000057628

Frondel, M., Horbach, J., \& Rennings, K. (2008). What triggers environmental management and innovation? Empirical evidence for Germany. Ecological Economics, 66(1), $153-160$. http://doi.org/10.1016/j.ecolecon.2007.08.016

Gladwin, T. N., Kennelly, J. J., \& Krause, T.-S. (1995). Shifting paradigms for sustainable development: implications for management theory and research. Academy of Management Review, 20(4), 874. http://doi.org/10.2307/258959

Gobble, M. M. (2012). Innovation and Sustainability. Research Technology Management 55.5, 55(5), 64-66. http://doi.org/10.5437/08956308X5505005

Govindarajulu, N., \& Daily, B. F. (2004). Motivating employees for environmental improvement. Industrial Management \& Data Systems, 104(4), 364-372. http://doi.org/10.1108/02635570410530775

Harris, L. C., \& Crane, A. (2002). The greening of organizational culture. Journal of Organizational Change Management, 15(3), 214-234. http://doi.org/10.1108/09534810210429273

Hart, S. L., \& Milstein, M. B. (2003). Creating sustainable value. Academy of Management Executive, 17(2), 5669.

Hemmelskamp, J. (1996). Environmental policy instruments and their effects on innovation (ZEW Discussion Papers No. 96-22).

Henriques, I., \& Sadorsky, P. (1996). The determinants of an environmentally responsive firm: an empirical approach. Journal of Environmental Economics and Management, 30, 381-395. http://doi.org/10.1006/jeem.1996.0026

Horbach, J. (2008). Determinants of environmental innovation-new evidence from German panel data sources. Research Policy, 37(1), 163-173. http://doi.org/10.1016/j.respol.2007.08.006

Julian, F., \& Wells, K. (2011). Greening your organisation: The case of the environment agency. In D. Bartlett (Ed.), Going Green: The Psychology of Sustainability in the Workplace (p. 18). London: BPS Publications.

Kane, A. (2011). Green recruitment, development and engagement. In D. Bartlett (Ed.), Going Green: The Psychology of Sustainability in the Workplace (p. 6). London: BPS Publications.

Kemp, R., \& Arundel, A. (1998). Survey indicators for environmental innovation (No. 8). IDEA Paper Series.

Keskin, D., Diehl, J. C., \& Molenaar, N. (2013). Innovation process of new ventures driven by sustainability. Journal of Cleaner Production, 45, 50-60. http://doi.org/10.1016/j.jclepro.2012.05.012

Labuschagne, C., Brent, A. C., \& van Erck, R. P. G. (2005). Assessing the sustainability performances of industries. Journal of Cleaner Production, 13(4), 373-385. http://doi.org/10.1016/j.jclepro.2003.10.007

Law, K. M. Y., \& Gunasekaran, A. (2012). Sustainability development in high-tech manufacturing firms in Hong Kong: Motivators and readiness. International Journal of Production Economics, 137(1), 116-125. http://doi.org/10.1016/j.ijpe.2012.01.022

Li, H., Jin, H., Hua, Y., Kong, C., \& Lin, L. (2011). Green research based on cultural three-hierarchy theory. Journal of Sustainable Development, 4(3), 196-198. http://doi.org/10.5539/jsd.v4n3p196

Linnenluecke, M. K., \& Griffiths, A. (2010). Corporate sustainability and organizational culture. Journal of World Business, 45(4), 357-366. http://doi.org/10.1016/j.jwb.2009.08.006

Margaretha, M., \& Saragih, S. (2013). Developing new corporate culture through green human resource practice. In International Conference on Business, Economics, and Accounting. Bangkok. Retrieved from http://www.caal-inteduorg.com/ibea2013/ejournal/059---Meily_Margaretha\&Susanti_Saragih--Developing_New_Corporate_Culture.pdf

Moldan, B., Janoušková, S., \& Hák, T. (2012). How to understand and measure environmental sustainability: indicators and targets. Ecological Indicators, 17, 4-13. http://doi.org/10.1016/j.ecolind.2011.04.033

Nidumolu, R., Prahalad, C. K., \& Rangaswami, M. R. (2009). Why Is now the key driver of innovation there's no alternative to sustainable development . Harvard Business Review, (September), 57-64. 
Oltra, V., \& Saint Jean, M. (2009). Sectoral systems of environmental innovation: An application to the French automotive industry. Technological Forecasting and Social Change, 76(4), 567-583. http://doi.org/10.1016/j.techfore.2008.03.025

Plank, R. (2011). Green behaviour: Barriers, facilitators and the role of attributions. In D. Bartlett (Ed.), Green behaviour: Barriers, facilitators and the role of attributions (p. 57). London: BPS Publications.

Ramus, C. A. (2001). Organizational support for employees: encouraging creative ideas for environmental sustainability. California Management Review, 43(3), 85-106.

Rave, T., Goetzke, F., \& Larch, M. (2011). The determinants of environmental innovations and patenting: Germany reconsidered (No. 97). Ifo Working Paper Series. Retrieved from http://ideas.repec.org/p/ces/ifowps/_97.html

Rehfeld, K.-M., Rennings, K., \& Ziegler, A. (2007). Integrated product policy and environmental product innovations: an empirical analysis. Ecological Economics, 61(1), 91-100. http://doi.org/10.1016/j.ecolecon.2006.02.003

Rennings, K. (2000). Redefining innovation - eco-innovation research and the contribution from ecological economics. Ecological Economics, 32(2), 319-332. http://doi.org/10.1016/S0921-8009(99)00112-3

Rodrigo, L. (2015). A holistic perspective on corporate sustainability drivers. Corporate Social Responsibility and Environmental Management, 22(1), 32-44.

Schein, E. H. (1990). Organizational Culture. American Psychologist, 45(2), 111.

Tokgöz, N., \& Önce, S. (2009). Corporate sustainability: alternative approach to traditional business management. Afyon Kocatepe Üniversitesi İBF Dergisi (in Turkish), 11(1), 249-275.

Triebswetter, U., \& Wackerbauer, J. (2008). Integrated environmental product innovation in the region of Munich and its impact on company competitiveness. Journal of Cleaner Production, 16(14), 1484-1493. http://doi.org/10.1016/j.jclepro.2007.09.003

Triguero, A., Moreno-Mondéjar, L., \& Davia, M. A. (2013). Drivers of different types of eco-innovation in European SMEs. Ecological Economics, 92, 25-33. http://doi.org/10.1016/j.ecolecon.2013.04.009

Turner, G. (2008). A comparison of the limits to growth with thirty years of reality. http://doi.org/10.1016/j.gloenvcha.2008.05.001

Uzgören, N. (2012). Bilimsel Araştırmalarda Kullanılan Temel İstatistiksel Yöntemler ve SPSS Uygulamaları (2. Edition). Bursa: Ekin Yayınevi.

WCED. (1987). Report of the World Commission on Environment and Development: Our Common Future. Retrieved January 20, 2016, from http://www.un-documents.net/wced-ocf.htm

Zibarras, L., \& Ballinger, C. (2010). Promoting environmental behaviour in the workplace: A survey of UK organisations. British Psychological Society Division of Occupational Psychology: Going Green Working Group Report. London. Retrieved from http://www.cubeproject.org.uk/wpcontent/uploads/2011/05/BPS_DOP_GoingGreenAtWorkBook.pdf\#page=86. 